\title{
MEMAHAMI KEDUDUKAN ARSIP SEBAGAI INSTRUMEN PERTAHANAN NEGARA
}

\author{
Eka Sujiwa Prabawa \\ Email:sayaekasujiwa@yahoo.com \\ Universitas Pertahanan Indonesia \\ (Indonesia Defense University)
}

\begin{abstract}
Abstrak Seiring dengan perkembangan lingkungan strategis saat ini, peran arsip sebagai alat bukti yang sah, bahan pertanggungjawaban pelaksanaan kegiatan pemerintahan serta pertahanan negara masih belum dipahami dengan baik. Indonesia sebagai negara yang memiliki banyak sekali pulau, di satu sisi menjadi modal bagi pembangunan dan kemajuan Indonesia, namun disisi lain, juga dapat menimbulkan ancaman bagi kedaulatan negara dan keutuhan NKRI. Kita mengenal sistem pertahanan negara yaitu bersifat semesta. Tugas menjaga keutuhan dan kedaulatan NKRI sejatinya merupakan hak sekaligus kewajiban seluruh komponen bangsa dan seluruh lapisan masyarakat, serta meliputi seluruh aspek termasuk dalam bidang kearsipan. Permasalahan yang ingin dijawab dalam kajian ini adalah (1) Bagaimana menyadarkan seluruh aspek bangsa akan pentingnya arsip? (2) Bagaimana mengelola arsip untuk kepentingan pertahanan negara? (3) Usaha apa yang bisa dilakukan untuk melestarikan arsip? Metode penelitian yang digunakan adalah deskriptif-analisis dengan membandingkan antara konsep dan teori yang bersumber pada studi kepustakaan, seperti peraturan perundang-undangan, literatur, jurnal, media massa, dan sebagainya untuk dianalisis secara mendalam. Kesimpulan dari kajian ini adalah bahwa arsip memiliki kedudukan sebagai instrumen pertahanan negara, maka dari itu diperlukan penanganan, pemberdayaan serta penanaman sejak dini akan pentingnya arsip.
\end{abstract}

Kata kunci: Arsip, Informasi, Sistem Pertahanan Negara

\section{PENDAHULUAN}

Perkembangan dan kepentingan global saat ini sungguh sangat dirasakan oleh bangsa Indonesia. Negara tercinta kita ini dikenal memiliki tiga gatra (trigatra), antara lain yaitu (1) letak geografis, (2) sumber daya alam (SDA), dan (3) kependudukan atau demografis. Potensi negeri tercinta ini bagaikan dua keping mata uang. Di satu sisi, ini menjadi modal bagi pembangunan dan kemajuan Indonesia. Pada sisi lain, ini menjadi daya tarik bagi munculnya ancaman, hambatan, tantangan, dan gangguan baik yang datang dari luar maupun dari dalam negeri. Sejarah telah membuktikan adanya ancaman-ancaman tersebut. Untuk menjaga keutuhan dan kedaulatan Negara Kesatuan Republik
Indonesia (NKRI) diperlukan sistem pertahanan negara yang modern dan kuat.

Ancaman nyata sekarang bukan perang secara fisik, tetapi lebih pada ancaman non militer. Tugas menjaga keutuhan dan kedaulatan NKRI sejatinya merupakan hak sekaligus kewajiban seluruh komponen bangsa dan seluruh lapisan masyarakat, serta meliputi seluruh aspek termasuk dalam bidang kearsipan. Arsip merupakan salah satu bagian dari sarana dan prasarana nasional untuk menunjang kepentingan pertahanan negara. Banyak informasi strategis yang disimpan di dalam arsip, seperti batas wilayah perbatasan, batas pulau pulau terdepan, kekayaan alam, sumber mineral, teknologi, budaya, dan 
kearifan lokal. Tentunya kita tidak mau terulang dengan kekalahan kita dalam mempertahankan pulau Sipadan dan Ligitan yang sekarang telah menjadi milik Malaysia. Banyak sekali kepentingan global negara lain yang patut kita waspadai. Disinilah peran arsip dalam mendukung pertahanan negara. Namun demikian, ada beberapa hal yang menjadi masalah dalam pengelolaan arsip terutama dalam konteks sistem pertahanan negara, yaitu kurang terjaganya informasi vital di dalam arsip, longgarnya akses terhadap arsip, dan lemahnya pengaman arsip maupun isi informasinya. Kajian ini akan mencoba menjawab pertanyaan-pertanyaan strategis, antara lain (1) Bagaimana menyadarkan seluruh aspek bangsa akan pentingnya arsip? (2) Bagaimana mengelola arsip untuk kepentingan pertahanan negara? (3) Usaha apa yang bisa dilakukan untuk melestarikan arsip?

Diharapkan kajian ini dapat memberi masukan atau saran dan langkah perbaikan strategis kepada para pengambil keputusan dalam upaya pembangunan sistem pertahanan negara yang modern dan kuat guna menjaga kedaulatan dan keutuhan NKRI. Arsip adalah rekaman kegiatan atau peristiwa dalam berbagai bentuk dan media sesuai dengan perkembangan teknologi informasi dan komunikasi yang dibuat dan diterima oleh lembaga negara, pemerintahan daerah, lembaga pendidikan, perusahaan, organisasi politik, organisasi kemasyarakatan, dan perseorangan dalam pelaksanaan kehidupan bermasyarakat, berbangsa, dan bernegara.

Sistem pertahanan negara adalah sistem pertahanan keamanan yang bersifat semesta yang melibatkan seluruh warga negara, wilayah, dan sumber daya nasional lainnya, serta dipersiapkan secara dini oleh pemerintah dan diselenggarakan secara total, terpadu, terarah, dan berlanjutan untuk menegakkan kedaulatan negara, keutuhan wilayah, dan keselamatan segenap bangsa dari segala ancaman. Sementara itu, pengertian kedaulatan negara dalam arti kenegaraan adalah kekuasaan penuh dan tertinggi dalam suatu negara untuk mengatur seluruh wilayahnya tanpa campur tangan dari pemerintah negara lain. Dalam kajian ini, kedaulatan NKRI meliputi wilayah dari Sabang sampai Merauke.

\section{METODOLOGI PENELITIAN}

Penulisan ini akan menelaah bagaimana memahami kedudukan arsip sebagai instrumen pertahanan negara. Arsip dan informasi di dalam arsip bisa menjadi modal dasar bagi pembangunan sistem pertahanan negara. Sebaliknya, apabila disalah gunakan atau jika salah kelola, informasi dalam arsip juga bisa menjadi boomerang bagi pertahanan negara. Penulisan kajian ini menggunakan metode deskriptif-analisis dengan membandingkan antara konsep dan teori yang bersumber pada studi kepustakaan, seperti peraturan perundang-undangan, literatur, jurnal, media massa, dan sebagainya untuk dianalisis secara mendalam.

\section{HASIL DAN PEMBAHASAN}

Berbagai upaya-upaya atau kegiatan yang dapat membahayakan kedaulatan dan keutuhan wilayah NKRI merupakan sebuah ancaman. Ancaman bisa datang baik dari dalam maupun luar negeri. Dalam era globalisasi, informasi semakin memegang peran strategis. Informasi dan penguasaan informasi menjadi sangat penting sebagai mana dinyatakan oleh Alvin Toffler, siapa menguasai informasi maka akanmenguasai dunia (Toffler, 1980). Oleh sebab itu, pengelolaan informasi, sebagaimana yang dikandung di dalam arsip, juga merupakan peluang yang bisa dimanfaatkan. Banyak informasi strategis yang terkandung di dalam arsip. Sebagai Lembaga Kearsipan Nasional, Arsip Nasional Republik Indonesia (ANRI) menyimpan khasanah arsip, seperti periode VOC, Hindia 
Belanda, masa interregnum Inggris, hingga masa setelah tahun 1945, yang berupa arsip kertas (arsip konvensional), peta, foto, film, rekaman suara, maupun dalam bentuk alih media microfilm atau bentuk digital dalam rangka pelestarian arsip. Contoh arsip tentang batas wilayah teritorial, termasuk pulau-pulau terdepan, pemerintah dalam hal ini Kementerian Pertahanan Republik Indonesia bisa memberdayakan antara lain khazanah arsip Algemeene Secretarie maupun peta-peta dalam Kartografi Indonesia, dalam rangka mendukung pertahanan negara. Pemberdayaan ini juga mencakup penetapan kebijakan yang tepat untuk diterapkan di berbagai daerah dalam rangka membangun sistem pertahanan negara yang modern dan kuat guna menjaga keutuhan dan kedaulatan NKRI. Arsip-arsip terkait wilayah perbatasan dan pulau-pulau terdepan perlu mendapatkan perhatian khusus karena bersinggungan langsung dengan pertahanan negara dan kedaulatan NKRI. Sementara itu, informasi di dalam arsip bisa memberikan gambaran bagaimana suatu negara memberdayakan atau mengelola wilayahnya termasuk di pulau-pulau terdepan. Keberadaan arsip sebagai bukti otentik dan informasi yang memuat pengelolaan suatu wilayah bisa menjadi faktor sangat menentukan dalam sengketa wilayah karena menjadi bukti siapa yang terlebih dahulu memiliki dan menguasai wilayah tersebut serta siapa yang terlebih dahulu telah mengelola wilayah tersebut.

Pemberdayaan arsip dan penggalian potensi informasi yang terkandung di dalam arsip bukanlah tanpa kendala. Pertama, pola pikir (mind set) banyak orang bahwa arsip hanyalah benda usang tidak bernilai yang kotor dan berdebu sehingga tidak pantas lagi untuk dilihat atau digali informasinya. Kedua, kendala bahasa seperti bahasa Belanda serta kondisi fisik arsip yang sudah rapuh dan/atau sulit dibaca. Ketiga, arsip adalah hasil samping atau sisa produk dar isuatu proses kegiatan.
Keempat, belum tentu semua pencipta arsip, termasuk lembaga pemerintah, memiliki sistem pengelolaan arsip yang terpadu. Kelima, dalam konteks sistem pertahanan negara, yaitu kurang terjaganya informasi vital di dalam arsip, longgarnya akses terhadap arsip, dan lemahnya pengamanan arsip maupun isi informasinya

\section{Kedudukan Arsip Sebagai Instrumen Pertahanan Negara}

Selama ini arti pentingnya arsip belum tertanam dalam jiwa setiap pencipta arsip. Mereka baru sadar akan fungsi arsip setelah terjadi suatu masalah yang membutuhkan bukti otentik yaitu arsip, kemudian belum optimalnya dalam mengelola dan melestarikan arsip. Pentingnya pengamanan terhadap informasi strategis negara pernah pula disampaikan oleh Prof. Dr. Purnomo Yusgiantoro selaku Menteri Pertahanan RI (2009-2014), bahwa "pengamanan informasi harus menjadi prioritas dalam upaya mencegah kebocoran informasi data strategis.

Dalam konteks ini, kita dapat melihat bahwa arsip dan informasi di dalam arsip merupakan salah satu sarana prasarana nasional yang dapat digunakan sebagai alat penunjang untuk kepentingan pertahanan negara. Oleh karena itu, pengelolaan arsip dan informasi di dalam arsip harus dilakukan secara komprehensif, yang melibatkan unsur-unsur

1. Subjek

Unsur-unsur subjek antara lain Arsip Nasional Republik Indonesia (ANRI), Dewan Perwakilan Rakyat (DPR), Presiden, Tentara Nasional Indonesia (TNI), Polri, serta Lembaga Ketahanan Nasional (Lemhanas).

2. Objek

Begitu penting dan strategisnya peran arsip dan informasi arsip, terutama di dalam konteks mendukung pertahanan negara yang modern dan kuat guna menjaga kedaulatan dan keutuhan NKRI, menempatkan seluruh stakeholder 
sebagai objek pengelolaan arsip dan informasi arsip. Penanganan dan pemberdayaan arsip berikut informasinya tidak bisa dilakukan secara parsial, tetapi harus secara terpadu, sistemik, dan komprehensif dengan melibatkan seluruh komponen bangsa dan negara yang ada. Seluruh stakeholder harus terlibat secara aktif, mulai dari pemangku kekuasaan eksekutif, legislatif, maupun yudikatif, dari tingkat pimpinan nasional, TNI, aparatur pemerintahan, aparatur penegak hukum, sampai dengan pihak swasta dan masyarakat umum. Seluruh stakeholder harus memahami dan dibangun kesadarannya akan peran strategis arsip dan pentingnya melestarikan arsip karena arsip merupakan identitas dan jati diri bangsa, serta sebagai memori, acuan, dan bahan pertanggungjawaban dalam kehidupan bermasyarakat, berbangsa, dan bernegara sehingga harus dikelola dan diselamatkan.

3. Cara atau Metode

Usaha membangun kesadaran akan pentingnya arsip dan informasi di dalam arsip terutama dalam mendukung pertahanan negara yang modern dan kuat guna menjaga keutuhan dan kedaulatan NKRI dapat dilakukan melalui metode-metode sebagai berikut:

$\begin{array}{llr}\text { a. Penetapan Rancangan Undang- } & \text { Undang (RUU) } \\ \text { undentang } \\ \text { Pengelolaan Sumber Daya }\end{array}$ Nasional Untuk Pertahanan Negara menjadi Undang-undang, agar Kementrian Pertahanan memiliki legalitas dalam mengelola sumber daya nasional dalam mendukung pertahanan negara.

b. Legislasi/Revisi, perlu dilakukan pengkajian dan penelaahan kembali terhadap peraturan perundangan yang telah ada, seperti UU No. 43/2009 tentang Kearsipan, UU No. 14/2008 tentang KIP, UU No. 3/2002 tentang Pertahanan Negara, dan regulasi-regulasi lainnya agar bisa tetap bersinergi, optimal, tidak tumpang-tindih, dan sesuai dengan kebutuhan zaman. Lebih lanjut, perlu dibuat regulasi khusus mengenai arsip-arsip strategis atau arsip terjaga yang memuat informasi vital rahasia negara, termasuk mengenai pertahanan negara.

c. Sosialisasi, perlu dilakukan sosialisasi peraturan perundangan yang berlaku terkait dengan kearsipan, keterbukaan dan ketertutupan informasi, serta pertahanan negara, sehingga stakeholder dapat memahami fungsi, peran, hak, dan kewajiban masing-masing. Jangan sampai potensi ini kemudian hanya dimanfaatkan oleh pihak luar, seperti para peneliti asing.

d. Edukasi, perlu dilakukan upayaupaya pembelajaran kepada para stakeholder mengenai peran strategis arsip dan informasinya dalam setiap sendi kehidupan berbangsa dan bernegara, khususnya dalam mendukung pertahanan negara yang kuat dan modern.

e. Pemanfaatan ilmu pengetahuan dan teknologi (iptek), seiring dengan perkembangan zaman dan lingkungan strategis maka iptek juga bisa dimanfaatkan untuk. Menunjang pemberdayaan potensi arsip dan informasi arsip. Perlu dibangun sebuah sistem kearsipan nasional dan sistem informasi kearsipan nasional yang terpadu dan terintegrasi. Sistem tersebut harus realible, yang bisa menjamin pemanfaatan arsip dan informasi arsip hanya kepada yang berhak di mana hak akses diatur sesuai dengan otoritas yang dimiliki oleh stakeholder. Namun demikian, tetap harus dijaga aspek kerahasiaan dan ketangguhan menghadapi usaha-usaha destruktif, seperti peretasan, penyebaran virus, maupun pencurian data dan informasi 
strategis, apalagi yang menyangkut sistem pertahanan negara (pembuatan sistem siber).

\section{KESIMPULAN}

Dari hasil pembahasan di atas dapat disimpulkan bahwa arsip dan informasi di dalam arsip merupakan salah satu sarana dan prasarana nasional yang dapat digunakan sebagai alat penunjang untuk kepentingan pertahanan negara. Penanganan dan pemberdayaan arsip berikut informasinya tidak bisa dilakukan secara parsial, tetapi harus secara terpadu, sistemik, dan komprehensif dengan melibatkan seluruh komponen bangsa dan negara yang ada serta dengan tetap memperhatikan paradigma nasional, perkembangan lingkungan strategis, dan kemajuan zaman. Perlu menanamkan sejak dini akan pentingnya arsip, sehingga para pencipta arsip akan melestarikan arsip yang bernilai guna. Perlu penanganan khusus terhadap arsip dan informasi di dalam arsip yang bernilai strategis sehingga tidak disalahgunakan oleh pihak-pihak yang tidak berhak, yang bisa mengancam kedaulatan NKRI, mungkin dengan menerapkan sistem siber dalam mendeteksi penyalahgunaan informasi arsip

\section{DAFTAR PUSTAKA}

Syahputra Andi.R. Peran strategis arsip dalam pembangunan sistem pertahanan dan keamanan guna menjaga keutuhan dan kedaulatan NKRI. Jurnal Kearsipan ANRI. Volume 11. 2016

Stoler, Ann Laura, Along the Archival Grain: Epistemic Anxieties and Colonial Common Sense, California: University Presses of California, Columbia and Princeton, 2008.

\section{Undang-Undang Dasar negara Republik} Indonesia Tahun 1945.
Ketetapan MPR No. II/MPR/1978 tentang Eka Prasetia Pancakarsa.

Undang-Undang Republik Indonesia Nomor 3 Tahun 2002 tentang Pertahanan Negara.

Undang-UndangRepublik Indonesia Nomor 14 Tahun 2008 tentang Keterbukaan Informasi Publik.

Undang-Undang Republik Indonesia Nomor 43 Tahun 2009 tentang Kearsipan.

Rancangan Undang-undang Republik Indonesia tentang Pengelolaan Sumber Daya Nasional Untuk Pertahanan Negara. 